\title{
ZKOUŠKY ČTENÁŘSKÝCH DOVEDNOSTÍ: NORMATIVNÍ ČESKÁ DATA PRO STUDENTY 9. TŘíD ZŠ A 1. ROČNÍKŮ SŠ
}

\author{
HANA SOKOLOVÁ ${ }^{1}$, HYNEK CÍGLER ${ }^{2}$ \\ ${ }_{1}$ Pedagogicko psychologická poradna Nový Jičín \\ ${ }^{2}$ Katedra psychologie, Fakulta sociálních studií Masarykovy univerzity
}

\begin{abstract}
Abstrakt: Vpředkládané studii jsou uvedena normativní česká data pro zkoušky čtenářských dovedností pro žáky 9. tříd základních škol a 1. ročníků středních škol. Dále byly identifikovány faktory, které mohou mít vliv na výkony žáků ve čtenářských zkouškách jedná se o věk žáků, kdy se rychlost hlasitého i tichého čtení překvapivě mírně zpomaluje, u žákủ 1. ročníků má pak na čtenářské výkony vliv typ navštěvované střední školy. Při srovnání výkonů žáků 9. tříd a 1. ročníků středních škol nebyly nalezeny téměř žádné rozdíly. Zabývali jsme se také schopnosti nástrojů odlišit děti s vývojovou poruchou učení, která se na našich datech projevila. Zkoumána byla souvislost rychlosti potichu čteného textu s porozuměním čtenému. Ověřovány byly také psychometrické charakteristiky jednotlivých zkoušek. Pro praktické využití odbornými pracovníky je v př́loze článku uveden metodický list pro práci s normami. Tato data pomohou speciálním pedagogům lépe zhodnotit kvalitu čtenářských dovedností žáků, a tedy i možnou potřebu podpůrných opatření ve vzdělání.
\end{abstract}

Klíčová slova: rychlost čtení; porozumění textu; normativní data; 9. tř́da ZŠ, 1. ročník SŠ, dyslexie

\section{Úvod}

V pedagogicko-psychologickém kontextu je nejčastější zakázkou diagnostika specifických vývojových poruch učení a chování, konkrétněji zejména hodnocení schopností a dovedností v oblasti čtení a psaní. V této práci se zabýváme zkouškami kvalit čtenářských dovedností, které mapujeme při diagnostice vývojové poruchy učení - dyslexie.

Poruchu čtení (dyslexii) chápeme v souladu s Veluttinem (1979, cit. dle Gough \& Tunmer, 1986) jako neschopnost naučit se číst navzdory normální inteligenci, dostatečné stimulaci a absenci neurologických a senzorických dysfunkcí, emocionálních nebo sociálních obtíží

\footnotetext{
${ }^{1}$ Pedagogicko psychologická poradna Nový Jičín, Žižkova 3, 74101 Nový Jičín

${ }^{2}$ Katedra psychologie, Fakulta sociálních studií MU, Joštova 10, 602 00, Brno

Doručeno do redakce: 15. 5. 2018

Př́prava publikace byla podpořena grantem GAČR GA17-09797S.
} 
nebo socioekonomickému znevýhodnění. Také v Mezinárodní klasifikaci nemocí (1992), kde je dyslexie řazena k poruchám psychického vývoje (F80-F89) - konkrétněji pod F81 Specifické vývojové poruchy školních dovedností, je zdůrazněno, že vývojový deficit není způsoben prostým následkem nedostatku př́ležitostí k učení, mentální retardací ani poraněním nebo onemocněním mozku. Etiologie poruchy a primární podstata zůstává nejasná, přestože již různé výzkumy prokázaly vliv neurobiologických a genetických faktorů na její rozvoj (Temple, 2002). Také Mezinárodní dyslektická společnost (2002) pokládá dyslexii za poruchu neurobiologického původu.

Dle Gougha a Tunmera (1986) je schopnost číst s porozuměním výsledkem vzájemného působení dvou oddělitelných dovedností: dekódování a porozumění jazyku. Jako dyslektiky pak označujeme ty, kteří špatně dekódují, ale dobře rozumějí jazyku. Obdobně je dyslexie charakterizována jako obtí̌e se správným a/nebo plynulým rozpoznáváním slov a oslabenou schopností hláskovat a dekódovat slova. Tyto obtíže zpravidla plynou z deficitu fonologické složky jazyka, která je v nepoměru k ostatním kognitivním schopnostem jedince (Mezinárodní dyslektická společnost, 2002).

Hlavním rysem dyslexie je dle MKN (2002) specifická a výrazná porucha ve vývoji schopnosti číst, přičemž může být postižena dovednost hlasitého čtení, porozumění čtenému a schopnost odpovídat na otázky vyžadující čtení. Mezinárodní dyslektická společnost (2002) chápe problémy s porozuměním čtenému a redukovanou zkušenost se čtením, způsobující u některých jedinců následně snížený rozvoj slovní zásoby a všeobecných znalostí, až jako sekundární důsledky neschopnosti naučit se plynule číst.

Při hodnocení čtenářských dovedností doporučuje Pokorná (2001) zjišt'ovat rychlost čtení, chyby při čtení, porozumění čtenému textu a chování dítěte při čtení. Caravolas a Volín (2005) doplňují, že u dyslektiků převažují potíže s dekódováním slov, je tedy snížena rychlost čtení a přítomno více chyb, porozumění čtenému je přinejmenším tak dobré jako u mladších žáků se stejnou schopností dekódovat.

Přestože v posledních letech vznikají nové standardizované diagnostické nástroje (napřr. Bednáŕová et al., 2015; Cimlerová, Pokorná, Chalupová et al., 2007), stále nejsou $\mathrm{k}$ dispozici soudobé české normy pro všechny věkové kategorie žáků ve školním věku.

Hlavním cílem této studie bylo získat normativní česká data pro skupinu žáků 9. tříd základních škol (dále ZŠ) a odpovídajících ročníkủ osmiletých gymnázií (dále uvádíme souhrnně „žáci 9. tř́íd, pokud není uvedeno jinak) a 1. ročníků středních škol (dále SŠ) pro zkoušky čtenářských dovedností. Studie byla součástí projektu, zaměřeného také na vznik normativních dat pro orientační neuropsychologickou zkoušku Test cesty pro věkovou skupinu 15-19 let (v tomto čísle, s. 1-20). Dílčím cílem bylo na získaných datech ověřit psychometrické charakteristiky použitých metod. 


\section{Metoda}

\section{Výzkumný soubor}

Byl použit záměrný, kvótní výběr, kdy kritériem pro rozřazení výzkumného souboru byl stanoven typ školy, kterou žák navštěvuje. U žáků 1. ročníků jsme z jednotlivých výročních zpráv všech středních škol, gymnázií a odborných učilišt' regionu Novojičínsko, ve kterém probíhal sběr dat, zjistili celkové poměrové zastoupení žáků na jednotlivých typech škol ve školním roce předcházejícím sběru dat (2015/2016). Dozvěděli jsme se, že 48,5 \% žáků studovalo na střední škole s maturitou, 25,9 \% žáků na gymnází́ch a 25,6 \% žáků si vybralo učební obor. U žáků 9. tříd a odpovídajícího ročníku osmiletého gymnázia jsme vycházeli z výroční zprávy Moravskoslezského kraje o stavu a rozvoji vzdělávací soustavy v MS kraji za školní rok 2015/2016 (2017), která udává, že v našem kraji odchází 7,3 \% žáků 5. tříd na osmileté gymnázium. Konkrétní údaje pro region Novojičínsko se nám pro tuto věkovou skupinu nepodařilo dohledat.

Následně jsme oslovili ředitele vybraných škol s žádostí o spolupráci tak, abychom co nejlépe zachovali výše zmíněné zastoupení žáků na jednotlivých školách také v našem výzkumném souboru. Výběr konkrétních škol pak probíhal př́ležitostným výběrem. Všichni ředitelé nám vyšli vstřric a umožnili nám realizaci výzkumu v některých tř́dách svých škol.

Výhodou zvoleného postupu výběru výzkumného souboru je dostupnost respondentů a možnost zajistit co nejreprezentativnější soubor z hlediska charakteristik, které jsme ve vztahu ke čtenářským zkouškám přepokládali jako významné (typ školy, ročník). To se nám podařilo relativně dobře u žáků 1. ročníků (gymnázia 29,2 \%, střední školy s maturitou 49,6\%, střední odborné učiliště $21,2 \%$ ), hůře u žáků 9 . tříd a odpovídajících ročníků osmiletého gymnázia (základní škola 71,6 \%, gymnázium 28,4 \%). Nevýhodou je absence záruk reprezentativity souboru z jiných hledisek a místní charakter norem. Důsledky podrobně zvažujeme v diskuzi.

\section{Použité metody}

\section{Hlasité čtení}

Text Legenda o vlčím hradu je převzat z baterie Diagnostika schopností a dovedností v oblasti čtení a psaní, vydané PPP Brno (Bednářová et al., 2015). Tento autorský text byl vytvořen pouze pro účely testu. Je určen jako souvislý text pro mapování čtenářských dovedností žáků 4. ročníku základní školy.

Přestože se jedná o text původně určený pro mladší žáky, než byla námi sledovaná populace, rozhodli jsme se daný text použít, a to zejména na základě klinických zkušeností speciálních pedagogů naší PPP, kteří mají s praktickým používáním čtenářských testů v kontextu pedagogicko-psychologického poradenství dlouhodobé zkušenosti. Ti vyhodnotili, že daný text je svou obtížností přiměřený pro hodnocení čtenářských 
dovedností současných žáků posledních ročníků základních škol a prvních ročníků středních škol.

Autorka metody doporučuje měřit čas a zaznamenat počet správně přečtených slov za 1 minutu, popř. 2 nebo 3 minuty, dále si zaznamenat průvodní projevy dítěte a čtenářskou techniku. Dále také všechny odlišně čtená slova od daného textu (tj. chyby) (Bednářová et al., 2015). My jsme se rozhodli zaznamenat počet přečtených slov a počet chyb za 1. a 2. minutu tak, aby měli respondenti možnost se „rozečíst“ a mohli jsme tak minimalizovat vliv netrénovaného čtení na jedné straně a únavy při čtení na straně druhé. Tento postup navíc umožnil odhad reliability ve smyslu vnitřní konzistence.

\section{Tiché čtení s porozuměním}

Text s názvem „O děvečce, která v Blaníku sloužila“ pro tiché čtení je z baterie Diagnostika specifických poruch učení u adolescentů a dospělých osob (Cimlerová et al., 2007). Autoři této baterie si jej vypůjčili z knihy Věnec pověstí a dějinných příběhů (Wenig, 1992 cit. dle Cimlerová et al., 2007). Text Děvečka je určen pro tiché čtení, k dispozici je srovnání výkonů s běžnou populací a se skupinou klientů PPP, dále se studenty dle typu střední školy, ve které jsou vzdělávání (SOŠ, SOU, gymnázium), a také dle pohlaví. Tato původní data použitá v originální studii (Cimlerová et al., 2007) vznikla z testování žáků 2. ročníku středních škol. Autoři udávají, že zkouška nám poskytuje 4 výstupy: počet přečtených slov za 1 minutu, zjištění stupně porozumění čtenému a kvalita reprodukce přečteného textu, průvodní projevy probanda při čtení a úroveň vyjadřovacích schopností (Cimlerová et al., 2007).

V našem výzkumu jsme se zaměřili na první dva zmiňované výstupy. Z hlediska rychlosti čtení jsme se rozhodli nechat všechny studenty přečíst 1 . odstavec textu (265 slov) a změřit čas, za jaký se to studentům povede. Rychlí čtenáři, kteří přečetli 1. odstavec za čas nižší než 2 minuty, byli po zkoušce porozumění vyzváni, aby pokračovali dále ke čtení 2 . odstavce. Obdobně následně ke čtení 3 . odstavce, pokud probandi stále nedosáhli souhrnného čtenářského času minimálně 2 minuty.

Důležité pro nás bylo také ověření porozumění čtenému. $\mathrm{V}$ manuálu je $\mathrm{k}$ tomuto uvedeno, že „po přečtení textu si necháme děj převyprávět a zhodnotíme stupeň porozumění a samostatnost reprodukce“ (Cimlerová et al., s. 27). Jelikož zde nejsou poskytnuta žádná konkrétnější vodítka, rozhodli jsme se přistoupit ke konstrukci vlastního nástroje.

Daný text si přečetli 3 pracovníci PPP, kteří s ním neměli žádnou zkušenost, a nezávisle na sobě vypsali klíčové informace daného příběhu. Následně své odpovědi porovnali a ty informace, na kterých se shodli aspoň 2 z nich, byly použity dále. Dalším kritériem pro zařazení jednotlivých položek bylo jejich rovnoměrné rozložení v textu. To bylo splněno první odstavec, který je nejdelší, obsahuje 12 položek (Př. Kam ovečka s děvečkou vešly? Do skály/do jeskyně), druhý odstavec 5 položek (Př. Jakou dostala děvečka odměnu? Smetí), třetí odstavec 7 položek (Př. Jak dlouho byla děvečka pryč? 1 rok). Poté výzkumníci formulovali standardizované otázky pro zjišt’ování porozumění a zapamatování požadovaných 
informací, stejně jako adekvátní odpovědi pro jednotlivé položky. Pilotní verze byla následně administrována 5 probandům, na základě jejich testování pak došlo k rozšriření možných správných odpovědí na jednotlivé položky. Domníváme se, že tento počet byl dostačující, nebot' se po administraci metody 3 respondentům již následné odpovědi opakovaly. Taktéž byly vytvořeny standardizované instrukce. Bylo rozhodnuto, že za správně podanou spontánní odpověd' budou uděleny 2 body, za správnou odpověd' na dotaz 1 bod, za špatnou nebo žádnou odpověd' 0 bodů. Znění všech položek zkoušky porozumění je uvedeno $v$ př́loze 1 .

\section{Výzkumný design}

Sběr dat probíhal přímo ve školách. Studenti byli nejdříve skupinově poučeni o průběhu a cílech výzkumu, byli informováni o dobrovolnosti a anonymitě šetření. Následně byli žáci, jejichž rodiče souhlasili s účastí svých dětí ve výzkumu, po jednom bráni do vyhrazené místnosti. Nejdříve dostali prostor $\mathrm{k}$ doplňujícím otázkám, poté s nimi byl proveden strukturovaný anamnestický rozhovor, následně jim byl administrován Test cesty (viz studie 1) a poté jsme prováděli zkoušku čtení. Polovina respondentů v pořadí konkrétněji popsaném dále (hlasité čtení - tiché čtení), druhá v opačném (tiché čtení hlasité čtení).

V rámci hlasitého čtení probandi četli celkově 2 minuty článek Legenda o vlčím hradu, instrukce zněla: „přečti nahlas tento článek, začni nadpisem a čti tak dlouho, dokud tě nezastavím. Při čtení dávej pozor, o čem čteš, protože se tě potom budu na př́běh ptát." Zaznamenáván byl počet přečtených slov, počet chybně přečtených slov - chyby opravené, neopravené, vše za 1 . minutu, 2 . minutu, celkově.

Následně probíhala zkouška tichého čtení. Probandi dostali text Děvečka s výrazně oddělenými odstavci a byla jim prezentována tato instrukce: „tento text budeš číst potichu, pouze nadpis přečti nahlas a pak pokračuj pro sebe tichým čtením. Až dočteš na konec prvního odstavce, řekneš mi. Je důležité, abys dával pozor, o čem čteš, protože budu chtít, abys mi př́běh povyprávěl." Administrátoři při čtení měřili čas. Poté byli probandi vyzváni "ted' mi řekni všechno, co si z př́běhu pamatuješ. Zkus mi povyprávět přečtený př́běh co nejkonkrétněji a nejpresněji". Administrátoři zaznamenávali podání klíčových informací do předem připraveného záznamového archu. Pokud některou z požadovaných informací probandi spontánně nepodali, byli následně dotázáni. Sběr dat $v$ jedné třídě probíhal zpravidla 2 vyučovací hodiny, proto měli respondenti minimální šanci si v průběhu šetření sdělit informace o průběhu testování.

\section{Popisné charakteristiky}

Celkově se projektu zúčastnilo 584 žáků z Moravskoslezského kraje z celkem 8 škol - 3 základních škol, 1 gymnázia, 2 odborných učilišt' a 2 středních škol. Jak bylo zmíněno výše, zkoušky čtenářských dovedností byly administrovány všem žákům 9. tř́d a 1. ročníků, žákům 2.-4. ročníků byla administrována pouze zkouška Test Cesty (viz Studie 1). 
Následující popis výzkumného souboru včetně informací v tabulce 1 se vztahuje výhradně k žákům, kterým byly administrovány zkoušky čtenářských dovedností. Těchto žáků se zúčastnilo celkem 204 z 319 oslovených (tj. účast 63,94 \%). Jednalo se o 135 dívek a 69 chlapců ve věku 14-17 let. V tabulce 1 je uvedeno rozložení výzkumného souboru z hlediska ročníku, pohlaví a typu navštěvované školy.

Tabulka 1 Popis výzkumného souboru

\begin{tabular}{|c|c|c|c|c|c|c|c|c|c|}
\hline & \multicolumn{2}{|l|}{$\overline{Z S ̌ S}$} & \multicolumn{2}{|c|}{ Gymnázium } & \multicolumn{2}{|l|}{ SŠ } & \multicolumn{2}{|l|}{ SOU } & \multirow{2}{*}{$\begin{array}{l}\text { Celke } \\
\mathrm{m}\end{array}$} \\
\hline & Dívky & Chlapci & Dívky & Chlapci & Dívky & Chlapci & Dívky & Chlapci & \\
\hline 9. tř́ída & 33 & 15 & 13 & 6 & 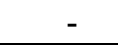 & & - & & 67 \\
\hline $\begin{array}{l}1 . \\
\text { ročník }\end{array}$ & - & - & 21 & 19 & 56 & 12 & 12 & 17 & 137 \\
\hline & 33 & 15 & 34 & 25 & 56 & 12 & 12 & 17 & \\
\hline Celkem & \multicolumn{2}{|c|}{48} & \multicolumn{2}{|c|}{59} & \multicolumn{2}{|c|}{68} & \multicolumn{2}{|c|}{29} & 204 \\
\hline
\end{tabular}

Z celkového počtu probandů nikdy nebylo v péči PPP 152 žáků, 52 ano - at' už v současnosti, nebo v minulosti. Aktuálně dochází do PPP 19 žáků - 16 pro vývojovou poruchu učení (dále VPU), 3 pro VPU i vývojovou poruchu chování (dále VPCH) zároveň.

\section{Postup zpracování dat}

Všechna dostupná data byla členy výzkumného týmu přepisována do programu MS Excel, následně byla převedena do programu IBM SPSS 20.0, ve kterém probíhala statistická analýza dat. Velikost efektu (Cohenovo $d$ ) byla počítána za využití kalkulačky dr. Beckera 3 . Žádný z respondentů nebyl ze statistické analýzy dat vyloučen.

\section{Výsledky}

Nejdříve jsme se zajímali o to, které faktory souvisí s výkonem žáků ve zkoušce čtení. Následně jsme tvořili normy a poté jsme hledali důkazy o reliabilitě a validitě použitých metod.

\section{Faktory související s výkonem žáků}

\section{Typ navštěvované školy}

Srovnávali jsme žáky 9. tříd základních škola a žáky odpovídajícího ročníku osmiletého gymnázia. Efekt navštěvované školy se potvrdil ve zkoušce rychlosti hlasitého čtení, $\mathrm{t}(65)=-3,33, \mathrm{p}=0,001$; s velkým efektem, Cohenovo $d=0,9$; rovněž v porozumění potichu čtenému textu $\mathrm{t}(64)=-2,56, \mathrm{p}=0,013$, se střední velikostí efektu, $d=0,7$, ve kterých dosáhli gymnazisté lepších výkonů. Naopak v chybovosti v nahlas čteném textu a ve zkoušce odrážející rychlost tichého čtení rozdíl nebyl nalezen, chybovost hlasitého čtení: $\mathrm{t}(65)=0,76, \mathrm{p}=0,453 ; d=0,2 ;$ rychlost tichého čtení: $\mathrm{t}(64)=1,75, \mathrm{p}=0,086 ; d=0,2$. Deskriptivní charakteristiky jsou uvedeny v Tabulce 2.

\footnotetext{
3 https://www.uccs.edu/ lbecker/
} 
Tabulka 2 Deskriptivní statistiky pro zkoušky čtení dle typu navštěvované školy

\begin{tabular}{|c|c|c|c|c|c|c|c|c|c|}
\hline \multirow{3}{*}{ Typ školy } & & \multicolumn{4}{|c|}{ Hlasité čtení ( 2 minuty) } & \multicolumn{4}{|c|}{ Tiché čtení (1. odstavec) } \\
\hline & & \multicolumn{2}{|c|}{ Počet slov } & \multicolumn{2}{|c|}{ Počet chyb } & \multicolumn{2}{|l|}{ Čas } & \multicolumn{2}{|c|}{ Porozumění } \\
\hline & $\mathrm{N}$ & $M$ & SD & $M$ & SD & $\mathrm{M}$ & SD & $\mathrm{M}$ & SD \\
\hline Gyn & 19 & 258,47 & 43,19 & 2,00 & 2,26 & 96,79 & 20,13 & 16,89 & 4,35 \\
\hline $\mathrm{ZS}$ & 48 & 224,38 & 35,49 & 2,48 & 2,37 & 107,87 & 24,51 & 13,57 & 4,92 \\
\hline Celkem & 66 & 234.04 & 40,57 & 2,34 & 2,33 & 104.68 & 2373 & 14.53 & 4.97 \\
\hline
\end{tabular}

U žáků 1. ročníků jsme srovnávali žáky odborných učilišt', středních odborných škol s maturitou a gymnázií. Efekt typu navštěvované střední školy na úroveň čtenářských dovedností žáků se potvrdil ve všech zkouškách - ve zkoušce hlasitého čtení v počtu správně přečtených slov: $F(2 ; 155)=21,10, p<0,001, \mu=0,46$, i v počtu chyb: $F(2$; $68,53)=11,15, p<0,001$, ve zkoušce tichého čtení v rychlosti čtení: $F(2 ; 67,74)=20,72$, $\mathrm{p}<0,001, \mu=0,44$, i porozumění čtenému: $\mathrm{F}(2 ; 69,35)=12,27, \mathrm{p}<0,001, \mu=0,36$. Dle předpokladů četli nejlépe studenti gymnázia - při hlasitém čtení přečetli nejvyšší počet slov za 2 minuty s nejnižší chybovostí, při tichém čtení přečetli daný úsek textu nejrychleji a zároveň získali nejvyšší počet bodů ve zkoušce porozumění čtenému. Naopak nejhůře se ve všech těchto zkouškách vedlo studentům učebních oborů.

Tabulka 3 Deskriptivní statistiky pro zkoušky čtení dle typu navštěvované střední školy

\begin{tabular}{|l|c|c|c|c|c|c|c|c|c|}
\hline \multirow{2}{*}{ Typ školy } & & \multicolumn{4}{l}{ Hlasité čtení (2 minuty) } & \multicolumn{3}{l|}{ Tiché čtení (1. odstavec) } \\
\cline { 3 - 10 } & & Počet slov & \multicolumn{2}{l}{ Počet chyb } & \multicolumn{2}{l|}{ Čs } & \multicolumn{2}{l|}{ Porozumění } \\
\hline & $\mathrm{N}$ & $\mathrm{M}$ & $\mathrm{SD}$ & $\mathrm{M}$ & $\mathrm{SD}$ & $\mathrm{M}$ & SD & M & SD \\
\hline SOU & 29 & 184,31 & 53,12 & 4,07 & 2,79 & 142,70 & 38,28 & 12,41 & 5,58 \\
\hline SŠ & 68 & 226,24 & 46,48 & 2,96 & 3,06 & 120,49 & 38,87 & 14,00 & 4,91 \\
\hline Gymnázium & 40 & 250,98 & 45,59 & 1,55 & 1,30 & 99,58 & 22,58 & 16,90 & 3,03 \\
\hline Celkem & 137 & 224,58 & 47,63 & 2,78 & 2,49 & 119,09 & 33,99 & 14,51 & 4,50 \\
\hline
\end{tabular}

\section{Ročník}

Ukázalo se, že úroveň čtení žáků 9. tříd je téměř totožná s úrovní čtení žáků 1. ročníku. Ve zkoušce hlasitého čtení přečetli žáci 9. tříd v průměru za 2 minuty stejně slov jako žáci 1. ročníku: $\mathrm{t}(165,66)=1,41, \mathrm{p}=0,160$, Cohenovo $d=0,2$; se srovnatelnou chybovostí: $\mathrm{t}(202)=-$ $1,12, p=0,263$, Cohenovo $d=-0,2$. Potichu čtenému textu rozumí žáci 9. tříd i 1. ročníků stejně dobře, $\mathrm{t}(201)=0,03, \mathrm{p}=0,979$, Cohenovo $d=0,01$. Pouze ve zkoušce tichého čtení dosáhli žáci 9. tříd lepšího výkonu - tzn. četli rychleji $(M=104,68, S D=23,78)$ než žáci 1. ročníku $(M=119,10, S D=37,75): t(187,18)=-3,31, p=0,001$, síla vztahu je střední Cohenovo $d=0,5$.

\section{Věk}

Ukázalo se, že ve věkovém rozmezí, ve kterém jsme administrovali zkoušky čtení (14-17 let) jsou čtenářské výkony žáků srovnatelné z hlediska chybovosti hlasitého čtení $\tau=0,11$, $\mathrm{p}=0,056$; a porozumění potichu čtenému textu: $\tau=0,03, p=0,592$, přičemž rychlost hlasitého čtení se $s$ věkem mírně zpomaluje: $\tau=-0,140, p=0,010$; stejně jako rychlost tichého čtení $\tau=0,169, p=0,002$. 


\section{Normy}

Na základě charakteristik, které se ukázaly ve vztahu ke čtenářským výkonům jako významné, jsou stratifikované normy (viz př́loha 2) a prezentujeme je pomocí percentilů a vážených skórů odpovídajících jednotlivým hrubým skórům. Percentily byly zjištěny na základě rozložení dat a převedeny na vážené skóry na základě McCallovy plošné transformace. Výsledky jsou předkládány $\mathrm{v}$ tabulkách zvlášt' pro jednotlivé zkoušky s výkony rozdělenými dle ročníku a rovněž typu navštěvované školy (ZŠ vs. gymnázium pro 9. ročníky, SOU vs. SŠ vs. gymnázium pro 1. ročníky). Rozdělení dle ročníku jsme upřednostnili před věkovými normami zejm. vzhledem $\mathrm{k}$ tradici speciálně pedagogické diagnostiky a důležitosti rozdělení skupin dle jednotlivých typů škol.

\section{Reliabilita a validita}

\section{Reliabilita zkoušky hlasitého čtení}

Reliabilita zkoušky hlasitého čtení byla odhadována metodou split-half. V průběhu čtení byl zaznamenán počet správně přečtených slov probandem po 1 . a po 2 . minutě. Odhad reliability je dopočítán pomocí tzv. Spearman Brownova prorockého vzorce. Protože je patrná významná souvislost výkonu ve zkoušce čtení s typem navštěvované školy, odhadli jsme reliabilitu zvlášt' pro jednotlivé typy škol.

Tabulka 4 Odhad reliability pro zkoušku hlasitého čtení

\begin{tabular}{|l|l|l|}
\hline & $\begin{array}{l}\text { Korelace počtu správně přečtených slov } \\
\text { za 1.a 2. Minutu }\end{array}$ & Odhad reliability (Spearman-Brown) \\
\hline Ž́ & $0,90^{* * *}$ & 0,95 \\
\hline SOU & $0,85^{* * *}$ & 0,92 \\
\hline SŠ & $0,90^{* * *}$ & 0,95 \\
\hline Gymnázium & $0,84^{* * *}$ & 0,91 \\
\hline Medián & & $\mathbf{0 , 9 5}$ \\
\hline
\end{tabular}

*** statisticky významná korelace na $\mathrm{p}<0,001$

Výsledná hodnota reliability je velmi dobrá. Taktéž počet chybně přečtených slov $v$ jednotlivých částech zkoušky spolu významně souvisí, $\tau=0,30, p<0,001$, proto je možné zkoušku hlasitého čtení považovat z hlediska obtížnosti za vyváženou.

\section{Reliabilita zkoušky tichého čtení}

Zajímala nás také souvislost výsledkủ žáků ve čtenářských zkouškách při tichém čtení $\mathrm{v}$ jednotlivých částech textu zhlediska rychlosti a porozumění čtenému. Z hlediska rychlosti čtení je možné části považovat za srovnatelné. Z hlediska porozumění jsou pak srovnatelné části 1 a 2 a 2 a 3 , souvislost mezi výkonem ve zkoušce porozumění čtenému v 1. a 3. části je malá (bližší vztah výkonu v jednotlivých částech viz Tabulka 5).

Velmi zajímavé je také srovnání výkonu z hlediska rychlosti čtení s výkonem ve zkoušce porozumění čtenému v odpovídajících částech. Ukázalo se, že tato souvislost je velmi malá až nulová. Navíc je patrná negativní souvislost výkonu ve zkoušce porozumění v 1 . části 
s rychlostí čtení 2 . i 3. části, tj. ti čtenáři, kteří získali více bodů za porozumění v 1. části, četli druhou a třetí část textu rychleji (potřebovali na přečtení méně času).

Tabulka 5 Přehled Personova korelačního koeficientu pro jednotlivé části zkoušky tichého čtení

\begin{tabular}{|c|l|l|l|l|c|c|c|}
\hline & \multicolumn{3}{|c|}{ 1. část } & \multicolumn{2}{l|}{ 2. část } & \multicolumn{2}{l|}{ 3. část } \\
\hline & & Čtení & $\begin{array}{l}\text { Porozu- } \\
\text { mění }\end{array}$ & Čtení & Porozumění & Čtení & $\begin{array}{l}\text { Porozu- } \\
\text { mění }\end{array}$ \\
\hline 1. část & Čtení & - & $-0,12$ & $0,61^{* * *}$ & $-0,02$ & $0,49^{*}$ & $-0,23$ \\
\hline & Porozumění & & - & $-0,34^{* * *}$ & $0,39^{* * *}$ & $-0,58^{*}$ & 0,23 \\
\hline 2. část & Čtení & & & - & $-0,19^{*}$ & $0,69^{* *}$ & $-0,16$ \\
\hline & Porozumění & & & & - & $-0,02$ & $0,69^{* *}$ \\
\hline 3. část & Čtení & & & & & - & 0,05 \\
\hline & Porozumění & & & & & & - \\
\hline
\end{tabular}

${ }^{*} \mathrm{p}<0,05 ;{ }^{* *} \mathrm{p}<0,01 ; * * * \mathrm{p}<0,001$

Pozn.: V tabulce jsou uvedeny pairwisedeleted korelace.

Reliabilita zkoušky tichého čtení byla odhadnuta prostřednictvím standardizované Cronbachovy alfy s využitím pairwisedeleted korelační matice (viz tab. 5). Pro rychlost čtení je reliabilita uspokojivá, $\alpha=0,816$, pro porozumění hraniční, $\alpha=0,699$.

V tabulce 6 jsou pro srovnání uvedeny výkony žáků v jednotlivých částech zkoušky porozumění. Je patrné, že úspěšnost žáků v dané zkoušce se v jednotlivých částech zvyšovala (vyjádřena procentuálně jako získané body vůči možnému maximálnímu zisku bodů). Je možné namítnout, že ke čtení s porozuměním 3. části textu se dostali pouze šikovnější čtenáři, avšak vzhledem k nízké souvislosti rychlosti čtení s kvalitou porozumění (viz výše) není tento argument pádný.

Tabulka 6 Srovnání výkonu žáků v jednotlivých částech zkoušky porozumění potichu čtenému textu

\begin{tabular}{|c|c|c|c|c|c|c|c|}
\hline & & \multirow{2}{*}{$\begin{array}{l}\text { Možný } \\
\text { počet bodů }\end{array}$} & \multicolumn{2}{|c|}{ Dosažený počet bodů } & \multirow[b]{2}{*}{ M } & \multirow[b]{2}{*}{ SD } & \multirow{2}{*}{$\begin{array}{l}\text { Průměrná } \\
\text { úspěšnost } \\
\text { (\%) }\end{array}$} \\
\hline & $\mathrm{N}$ & & Min & Max & & & \\
\hline $\begin{array}{l}\text { Část } \\
1\end{array}$ & 203 & $0-24$ & 0 & 23 & 14,52 & 4,89 & 60,5 \\
\hline $\begin{array}{l}\text { Část } \\
2\end{array}$ & 135 & $0-10$ & 0 & 10 & 7,15 & 2,20 & 71,5 \\
\hline $\begin{array}{l}\text { Část } \\
3\end{array}$ & 18 & $0-14$ & 8 & 14 & 12,39 & 1,88 & 88,5 \\
\hline
\end{tabular}

\section{Konvergentní validity}

Validitu dané metody jsme se snažili prokazovat pomocí hledání vztahu výsledků v daném testu s dalšími relevantními proměnnými. 
Tabulka 7 Přehled souvislosti výsledku ve čtenářských zkouškách s dalšími kritérii

\begin{tabular}{|l|c|c|c|}
\hline Kritérium & Hlasité čtení & Tiché čtení & Tiché čtení - porozumění \\
\hline Známka z M & $-0,14^{* *}$ & $0,20^{* * *}$ & $-0,19^{* *}$ \\
\hline Známka z JČ & $-0,27^{* * *}$ & $0,29^{* * *}$ & $-0,21^{* * *}$ \\
\hline $\begin{array}{l}\text { Průměr všech známek } \\
\text { na } \\
\text { vysvědčení }\end{array}$ & $-0,25^{* * *}$ & $0,28^{* * *}$ & $-0,15^{*}$ \\
\hline Vzdélání matky & $0,15^{* *}$ & $-0,20^{* * *}$ & $0,21^{* * *}$ \\
\hline Vzdělání otce & $0,16^{* *}$ & $-0,22^{* * *}$ & 0,11 \\
\hline Výsledek v TMT A & $-0,29^{* *}$ & $0,40^{* *}$ & $-0,09$ \\
\hline Výsledek v TMT B & $-0,23^{* *}$ & $0,29^{* *}$ & $-0,22^{* *}$ \\
\hline
\end{tabular}

* $\mathrm{p}<0,05 ;{ }^{* *} \mathrm{p}<0,01 ;{ }^{* * *} \mathrm{p}<0,001$

Pozn.: Tabulka obsahuje pořadové Kendallovy korelační koeficienty.

Z výše uvedené tabulky je možné vyčíst souvislost výsledku čtenářských zkoušek se studijními výsledky žáků, taktéž se vzděláním rodičů a s výsledky v Testu cesty (TMTA i TMTB). Patrný je nejtěsnější vztah všech uvedených charakteristik s výsledky žáků ve zkoušce tichého čtení, naopak nejvolnější jsou vztahy těchto charakteristik s výsledky žáků ve zkoušce porozumění čtenému. Nejtěsnější vztah s výsledky všech čtenářských zkoušek pak má známka z českého jazyka na posledním vysvědčení.

\section{Kriteriální validita}

\section{Hlasité čtení}

V průměru žáci s poruchami učení vedeni s touto diagnózou v PPP $(n=19)$ přečetli hlasitým čtením za 2 minuty menší počet slov ( $M=165,47, S D=41,75)$ než žáci bez poruchy učení potvrzené v PPP $(n=185, M=234,08, S D=45,45)$. Tento rozdíl je signifikantní $\mathrm{W}=653,5, \mathrm{z}=-5,28, \mathrm{p}<0,001$, síla vztahu je střední $r=0,37$ (podle Fielda, 2013). Statisticky významný rozdíl je patrný také v chybovosti při hlasitém čtení, kdy žáci vedeni v PPP pro VPU četli s výrazně vyšší chybovosti $(M=5,74, S D=3,93)$ než žáci, kteří v PPP pro VPU vedeni aktuálně nejsou $(M=2,32, S D=2,22), W=17941, z=-4,23, p<0,001$, síla vztahu je střední $r=0,30$.

\section{Tiché čtení}

V průměru žáci s poruchami učení vedeni s touto diagnózou v PPP (n=19) četli tichým čtením předložený text pomaleji $(M=148,95, S D=45,59)$ než žáci bez poruchy učení potvrzené v PPP $(n=184, M=110,85, S D=31,12)$. Tento rozdíl je signifikantní $W=17739,0$, $\mathrm{z}=-4,22, \mathrm{p}<0,001$, síla vztahu je střední $\mathrm{r}=0,30$. V porozumění potichu čtenému textu není mezi žáky s poruchami učení $(M=16,32, S D=4,69)$ a žáky bez poruch učení potvrzených $\mathrm{v}$ PPP rozdíl $(M=14,33, S D=4,88), W=18$ 319,5, z=-1,84, p=0,065, síla vztahu je malá $r=0,13$.

\section{Obsahová validita}

Pro minimalizaci vlivu pořadí čtení na výkon četla část probandů nejdříve potichu a poté nahlas, druhá část nejdříve nahlas a poté potichu. Ukázalo se, že toto mělo pouze malý vliv na výkony. 
Ve zkoušce hlasitého čtení podali z hlediska rychlosti mírně lepší výkon žáci, kteř́i četli nejdříve nahlas a poté potichu ( $\mathrm{n}=104, \mathrm{M}=235,00 ; \mathrm{SD}=44,36)$ než ti, kteř́ četli nejprve potichu a poté nahlas $(\mathrm{n}=100, \mathrm{M}=220,09, \mathrm{SD}=53,04), \mathrm{t}(202)=2,18, \mathrm{p}=0,030 . \mathrm{Z}$ hlediska chybovosti při čtení není ve výkonech žáků rozdíl: $\mathrm{t}(202)=0,34, \mathrm{p}=0,690$.

Ve zkoušce tichého čtení nemělo pořadí čtení vliv na výkony probandů - at' už co se týče rychlosti čtení $\mathrm{t}(174,68)=-1,76, p=0,080$ nebo porozumění čtenému $t(201)=-1,03$, $\mathrm{p}=0,889$.

\section{Diskuze}

\section{Normativní data}

Na základě faktorů, které se ukázaly jako významně ovlivňující výsledky čtenářských zkoušek, jsme stratifikovali normy. Výsledky námi provedené studie poukazují na souvislost typu navštěvované střední školy a úrovně čtenářských dovedností. Ve shodě s dřívějšími výsledky Cimlerové a kolegů (2007) se potvrdilo, že nejlépe čtou studenti gymnázií, následovaní studenty středních odborných škol a studenty odborných učilišt'. Také u žáků 9. tř́íd byl patrný lepší čtenářský výkon žáků víceletých gymnázií v porovnání s žáky základních škol.

Zajímavé je také srovnání výkonů žáků 9. tříd a 1. ročníků středních škol, ve kterém překvapivě nebyl prokázán rozdíl v rychlosti a kvalitě hlasitého čtení ani v porozumění potichu čtenému textu. Jediný rozdíl se projevil v rychlosti potichu čteného textu ve prospěch žáků 9. ročníků. Jedním z možných vysvětlení tohoto překvapivého výsledku je fakt, že z žáků 9. tř́d základních škol se projektu zúčastnilo nejméně ze všech oslovených žáků (39,68 \%), přičemž u žáků odpovídajícího ročníku osmiletého gymnázia byla účast $82,76 \%$ ze všech oslovených. My obě tyto skupiny pro účely norem považujeme za žáky 9. tříd. Účast studentů 1. ročníků se pak významně nelišila dle typu navštěvované školy a v souhrnu činila 79,23 \%. Navíc zastoupení žáků 1. ročníků dle typu navštěvované stř̌ední školy v našem souboru lépe reprezentuje skutečné zastoupení žáků v populaci, než je tomu u žáků 9. tř́d, kde je v našem výzkumném souboru významně více žáků gymnázií oproti žákům základních škol, než je v běžné populaci (28,36 \% proti 7,28 \%). Tyto faktory jsou limitem studie a pravděpodobně hrají roli právě ve zjištěné srovnatelné čtenářské výkonnosti žáků 9. tříd a 1. ročníků - jinými slovy větší zastoupení gymnazistů mezi žáky 9. tř́́d v našem vzorku než ve skutečnosti mohlo nadhodnotit souhrnné výkony žáků 9 . ročníků oproti žákům 1. ročníků středních škol. Tento limit však překonává rozdělení norem dle typu navštěvované školy (proti souhrnným normám bez ohledu na tento faktor), proto bychom chtěli výrazně doporučit praktické využívání norem nikoliv souhrnných, ale rozdělených dle typu navštěvované školy.

Při věkovém srovnání výkonu žáků se na našich datech ukázalo, že rychlost hlasitého i tichého čtení se s věkem mírně zpomaluje (ve věkové skupině 14-17 let). Přestože se nejednalo o výrazné zhoršování výkonů, byly rozdíly v jednotlivých věkových skupinách statisticky průkazné. Na základě těchto dat se zdá, že je důležitější fyzický věk žáků než 
počet let výuky čtení. Dle našich zjištění dosud nebyla minimálně v českém prostředí provedena studie zabývající se vývojem čtenářských dovedností ve starším školním věku a v dospívání (týkající se např. vývoje rychlosti čtení, schopnosti porozumění, aj.), bylo by proto velmi užitečné se na toto téma blíže zaměřit.

Limitem prezentovaných normativních dat kromě výše zmíněné nízké poměrové účasti žáků 9. tř́d ve srovnání s žáky gymnázií i žáky stř̌edních škol je také fakt, že data byla sbírána vjednom regionu České republiky. Sice předpokládáme, že rozdíly mezi jednotlivými kraji v rámci České republiky budou spíše menší, nelze to však vyloučit. Bylo by vhodné studii replikovat také v jiných regionech ČR a ověřit tak získané informace.

\section{Reliabilita a validita použitých metod}

Ukázalo se, že použité texty jsou reliabilním a validním ukazatelem čtenářských schopností žáků. Reliabilitu textu „Legenda o vlčím hradu“ jsme dokazovali metodou splithalf, výsledná hodnota je velmi dobrá ( $\mathrm{r}=0,97)$. Text „Děvečka, která v Blaníku sloužila“ je taktéž možné považovat za reliabilního ukazatele čtenářských dovedností - pro rychlost čtení je reliabilita uspokojivá, $\alpha=0,816$, pro porozumění hraniční, $\alpha=0,699$, avšak stále př́pustná.

Zkouška porozumění čtenému, která byla konstruována pro účely této studie, je z hlediska praktického použití zkoušky v celém rozsahu kontroverzní. Ukázala se významná souvislost výkonu ve zkoušce porozumění $\mathrm{v} 1$. a 2 . části $(\mathrm{r}=0,34)$, souvislost počtu bodů obdrženého ve zkoušce porozumění ve 2 . a 3. části je ještě výraznější $(\mathrm{r}=0,69)$. Naopak při srovnání výkonu v1. a 3. části nenacházíme významnou souvislost. Tyto výsledky si interpretujeme tak, že ke zlepšování výkonu docházelo kvůli efektu zácviku, kdy žáci již byli připraveni, že bude porozumění ověrováno (a také jakým způsobem), a proto dosáhli lepšího výkonu. Argument proti tomuto tvrzení by mohl být ten, že k 3. části textu se dostali pouze nejlepší čtenáři (resp. nejrychlejší), avšak vzhledem k výše zmiňované nízké souvislosti rychlosti tichého čtení a výkonu ve zkoušce porozumění ztrácí tato námitka sílu. Další možností je, že jednotlivé části zkoušky nejsou stejně obtížné. Vzhledem k těmto zjištěním jsme se pro praktické využití rozhodli využívat pouze 1. část zkoušky porozumění (vážící se k přečtenému 1. odstavci) - prvním důvodem pro toto rozhodnutí je zamezení efektu zácviku, druhým pak možnost srovnání se všemi žáky (tedy nikoliv pouze s rychlými čtenáři, kteř́ pokračovali dál $\mathrm{k}$ dalším odstavcům), což rezultuje také $\mathrm{v}$ třetí důvod - možnost srovnání s největší normativní skupinou. Další dvě části zkoušky porozumění doporučujeme využívat pouze pro orientační srovnání.

Velmi zajímavé je podle našeho názoru také zjištění, že souvislost rychlosti potichu čteného textu s porozuměním čtenému dané části textu je velmi malá, prakticky žádná. Z toho důvodu vnímáme jako velmi potřebné při diagnostice hodnotit zvlášt' oba tyto aspekty a nepředpokládat, že rychlí čtenáři budou automaticky lepší v porozumění čtenému, nebo naopak že pomalejší čtenáři jsou schopni text lépe vnímat a více mu tak rozumí. Pokud se však podíváme na skupinu žákủ, kteří dosáhli kvalitního výkonu ve zkoušce porozumění již v 1 . části, zjistíme, že tito žáci četli rychleji 2. i 3. část textu. 
Analogicky pak žáci se slabším porozuměním 1. části textu pak četli pomaleji 2. a 3. část textu. Domníváme se, že je to z toho důvodu, že po přečtení první části textu, kdy se studenti dozvěděli o formě ověřování porozumění, ti se slabším výsledkem zvolnili, aby byli schopni lépe vnímat také obsah čteného.

Důkazy o validitě použitých diagnostických nástrojů jsme hledali ověřováním jejich schopnosti diskriminovat na vysoké hladině významnosti mezi různými skupinami, konkrétně mezi dětmi bez a s poruchou učení. Dle očekávání a v souladu s Cimlerovou a kolegy (2007) podali žáci s diagnostikovanými vývojovými poruchami učení horší čtenářské výkony - a to jak v rychlosti a kvalitě nahlas čteného textu, tak v rychlosti tichého čtení. Srovnatelný byl výkon těchto žáků s běžnými žáky ve zkoušce porozumění potichu čtenému textu, což odpovídá teorii o tom, že žáci s vývojovou poruchou učení mají potíže zejména s dekódováním informací, ale úroveň jejich porozumění čtenému textu je minimálně stejná jako jejich schopnost dekódovat text (Caravolas \& Volín, 2005, Gough \& Tunmer, 1986). V této souvislosti je však potřeba zmínit, že v námi provedeném výzkumu nebylo rozlišováno, jako vývojovou poruchou učení žáci trpí (zejména z důvodu nejasných výpovědí studentů).

Další zdroje důkazů o validitě jsme hledali pomocí zkoumání vztahu výsledků ve čtenářských zkouškách s dalšími kritérii. Ukázala se statisticky významná souvislost výkonu ve všech čtenářských zkouškách se školními známkami na posledním vysvědčení (M, JČ, celkový průměr) - čím horší má žák studijní výsledky, tím hůře se mu vedlo nahlas přečetl méně slov za daný časový úsek, při tichém čtení potřeboval na přečtení 1. odstavce delší čas a získal méně bodů ve zkoušce porozumění čtenému. Nejtěsnější vztah je možné sledovat při hodnocení souvislosti výkonu ve čtenářských zkouškách se známkou z českého jazyka. Patrná je také souvislost čtenářských výkonů se vzděláním obou rodičů a výsledky v obou částech Testu cesty. Co se týká jednotlivých čtenářských zkoušek - nejvíce závislá na sledovaných charakteristikách je zkouška tichého čtení, následovaná zkouškou hlasitého čtení, naopak zkouška porozumění čtenému textu je na známkách i vzdělání rodičů relativně nezávislá.

V předkládané studii jsou uvedena normativní česká data pro zkoušky čtenářských dovedností pro žáky 9. tříd základních škol a 1. ročníků středních škol, identifikovány faktory, které mohou mít vliv na výkony žáků ve čtenářských zkouškách, a prezentovány také zjištěné psychometrické charakteristiky jednotlivých zkoušek. Pro praktické využití odbornými pracovníky je v př́loze č. 2 uveden metodický list pro práci s normami. Tato data pomohou pracovníkům pedagogicko-psychologických poraden lépe zhodnotit kvalitu čtenářských dovedností žáků. Ukázalo se, že použité texty jsou schopny odlišit žáky s vývojovou poruchou učení a tedy s potřebou podpůrných opatření ve vzdělávání. Bylo by vhodné provést další studii se zařazením většího počtu žáků s diagnostikovanou vývojovou poruchou učení - konkrétně dyslexií, abychom měli přesnější informace o výkonu těchto žáků. Důležité je dle našeho názoru také rozvíjet - tvořit nové a zpřesňovat již existující - nástroje pro diagnostiku porozumění čtenému textu a průběžně 
TESTFÓRUM, 2018, č. 11, s. 21-36

www.testforum.cz Hana Sokolová, Hynek Cígler: Zkoušky čtenářských dovedností: Normativní česká data pro studenty 9. tř́íd ZŠ a 1. ročníků SS̆

aktualizovat jejich normy. Velmi zajímavé by dle našeho názoru bylo také blíže prozkoumat čtenářský vývoj žáků druhého stupně základních škol a středních škol. 


\section{Zdroje}

Bednářová, J. et al. (2015). Diagnostika schopností a dovedností v oblasti čtení a psaní. PPP Brno.

Caravolas, M. \& Volín, J. (2005). Baterie diagnostických testů gramotnostních dovedností pro žáky 2. až 5. tř́d. Praha: IPPP.

Cimlerová, P., Pokorná, D. Chalupová, E. et al. (2007). Diagnostika specifických poruch učení u adolescentů a dospélých osob. Praha: IPPP.

Field, A. (2013). Discovering Statistics Using IBM SPSS. Discovering Statistics Using SPSS (4th ed.). London: SAGE. https://doi.org/10.1234/12345678

Gough, P. B., \& Tunmer, W. E. (1986). Decoding, Reading, and Reading Disability. Remedial and Special Education, 1(7), 6-10.

Mezinárodní dyslektická společnost (2002), dostupné z https://dyslexiaida.org/definition-ofdyslexia

Mezinárodní statistická klasifikace nemocí a přidružených zdravotních problémů: 10. revize. (1992). Praha: Bomton Agency.

Pokorná, V. (2001). Teorie a náprava vývojových poruch učení a chování. Praha: Portál.

Temple, E. (2002). Brain mechanisms in normal and dyslexic readers. Current Opinion in Neurobiology, 12(2), 178-183. https://doi.org/10.1016/S0959-4388(02)00303-3 


\title{
Hana Sokolová, Hynek Cígler (2018): Reading ability tests: Normative Czech data for students of 9th grade primary school and 1st grade secondary school
}

\begin{abstract}
In the presented study, we provide normative Czech data for reading abilities tests for students of 9th grade primary school and 1st grade secondary school. Factors related to reading ability test scores were identified - speed of loud as well as quiet reading is surprisingly mildly slowing down with growing age, and the type of attended secondary school is a factor related to reading tests performance in students of the $1^{\text {st }}$ grade secondary school. There is no difference found when comparing results of students of $9^{\text {th }}$ grade primary school to students of 1st grade secondary school. The ability of these tests to identify students with dyslexia was explored and confirmed. The relation of quiet reading speed and comprehension of the text was explored. Psychometric characteristics of individual tests were also examined. There is a methodical list provided in the appendix for practical use of normative data. The presented data will help special educators to better assess the reading ability of students and to identify students with special needs more accurately.
\end{abstract}

Key words: Reading speed, comprehension, normative data, 9th grade primary school students, 1st grade secondary school students 


\section{Příloha 1: Zkouška porozumění - celé znění}

\begin{tabular}{|c|c|c|}
\hline $\begin{array}{l}\text { Číslo } \\
\text { položky }\end{array}$ & Otázka: & Možnosti odpovědí \\
\hline \multicolumn{3}{|c|}{ 1. odstavec } \\
\hline 1 & Ve vsi pod jakou horou se příběh odehrává & pod Blaníkem \\
\hline 2 & Kdy byl oběd? & pozdě/ji než obvykle, po poledni \\
\hline 3 & Co se ozvalo na návsi během oběda? & trouba, slouha troubil/houkal/svolával \\
\hline 4 & Proč slouha troubil? & $\begin{array}{l}\text { at’ vyženou ovce, protože bral ovce, sháněl } \\
\text { ovce }\end{array}$ \\
\hline 5 & Co zjistila děvečka, když přišla na náves? & $\begin{array}{l}\text { že už je slouha pryč, že slouhu nestihla, že } \\
\text { jde pozdě/ nestihla to }\end{array}$ \\
\hline 6 & Jak to vyřešila? & musela odvést ovce sama \\
\hline 7 & Co se stalo, když hnala ovce? & jedna se zaběhla, oddělila od stáda, utekla \\
\hline 8 & Kam ovečka s děvečkou vešly? & do skály \\
\hline 9 & Co se stalo se skálou sotva byly uvnitř? & zarachotilo se, skála se zavřela \\
\hline 10 & Jak se cítila děvečka, když se skála zavřela? & $\begin{array}{l}\text { byla ulekaná, vystrašená .... synonyma } \\
\text { strachu }\end{array}$ \\
\hline 11 & Co viděla děvečka uvnitř skály? & spící vojsko, vojáky \\
\hline 12 & Co dostala děvečka za úkol? & uklidit jim \\
\hline \multicolumn{3}{|c|}{ 2. odstavec } \\
\hline 13 & Jakou dostala děvečka odměnu? & (plnou zástěru) smetí + synonyma pro smetí \\
\hline 14 & $\begin{array}{l}\text { Co si děvečka pomyslela, když odměnu } \\
\text { dostala? }\end{array}$ & že o ni nestojí, bála se to říct \\
\hline 15 & Co udělala děvečka se smetím v zástěře? & část vysypala, část si nechala \\
\hline 16 & Proč si část odměny nechala? & $\begin{array}{l}\text { aby jí doma věřili, aby doma ukázala, kde } \\
\text { byla }\end{array}$ \\
\hline 17 & $\begin{array}{l}\text { Jaká byla denní doba, když dívka vystoupila } \\
\text { ze skály? }\end{array}$ & $\begin{array}{l}\text { stmívalo se, večer, bylo pozdě hnát ovci na } \\
\text { pastvu }\end{array}$ \\
\hline \multicolumn{3}{|c|}{ 3. odstavec } \\
\hline 18 & $\begin{array}{l}\text { Jak se tvářili doma, když děvečka přišla } \\
\text { domů? }\end{array}$ & $\begin{array}{l}\text { byli vyjevení, překvapení, divili se, zírali na } \\
\text { ni }\end{array}$ \\
\hline 19 & Jak dlouho byla děvečka pryč? & 1 rok \\
\hline 20 & Co se stalo se smetím v zástěře? & změnilo se zlato/zlaté/poklad \\
\hline 21 & Kam potom děvečka s čeledínem šli? & $\begin{array}{l}\text { do lesa, ke skále, tam kde vysypala smetí, } \\
\text { hledat smetí }\end{array}$ \\
\hline 22 & Co tam našli? & nic \\
\hline 23 & Co se zlatem udělala? & koupila chalupu/pole \\
\hline
\end{tabular}




\begin{tabular}{|l|l|l|}
\hline 24 & $\begin{array}{l}\text { Jak děvečka vzpomínala na dobu, kdy sloužila } \\
\text { v Blaníku? }\end{array}$ & $\begin{array}{l}\text { št'astně, ráda, vyprávěla vnoučatům, } \\
\text { všechno pozitivní }\end{array}$ \\
\hline
\end{tabular}

\section{Příloha 2: Metodický list k práci se čtenářskými zkouškami}

Celkově se projektu zúčastnilo 204 žáků (z celkem 319 oslovených, tj. účast 63,94 \%) 9. tříd základních škol (a odpovídajícího ročníku osmiletého gymnázia) a 1. ročníků středních škol z okresu Nový Jičín (MS kraj). Jednalo se o 135 dívek a 69 chlapcủ ve věku 14-17 let z celkem 8 škol - 3 základních škol, 1 gymnázia, 2 odborných učilišt' a 2 středních škol.

Tabulka 1 Popis výzkumného souboru

\begin{tabular}{|c|c|c|c|c|c|c|c|c|c|}
\hline & \multicolumn{2}{|l|}{$Z S$} & \multicolumn{2}{|c|}{ Gymnázium } & \multicolumn{2}{|l|}{ SŠ } & \multicolumn{2}{|l|}{ SOU } & \multirow{2}{*}{\begin{tabular}{|l|} 
Celke \\
$\mathrm{m}$ \\
\end{tabular}} \\
\hline & Dívky & Chlapci & Dívky & Chlapci & Dívky & Chlapci & Dívky & Chlapci & \\
\hline 9. třída & 33 & 15 & 13 & 6 & 2 & & - & & 67 \\
\hline $\begin{array}{l}1 . \\
\text { ročník }\end{array}$ & - & - & 21 & 19 & 56 & 12 & 12 & 17 & 137 \\
\hline & 33 & 15 & 34 & 25 & 56 & 12 & 12 & 17 & \\
\hline Celkem & \multicolumn{2}{|c|}{48} & \multicolumn{2}{|c|}{59} & \multicolumn{2}{|c|}{68} & \multicolumn{2}{|c|}{29} & 204 \\
\hline
\end{tabular}

Z celkového počtu probandů nikdy nebylo v péči PPP 152 žáků, 52 ano - at' už v současnosti, nebo v minulosti. Aktuálně dochází do PPP 19 žáků - 16 pro vývojovou poruchu učení (dále VPU), 3 pro VPU i vývojovou poruchu chování (dále VPCH) zároveň.

\section{Administrované zkoušky:}

1. Hlasité čtení: text Legenda o Vlčím hradu 4- tento text čtou žáci a studenti nahlas, po dobu 2 minut (čas se začíná měřit po přečtení nadpisu). Při čtení se zaznamenává počet chybně přečtených slov. Pro vyhodnocení testu nás tedy zajímá:

\section{- počet správně přečtených slov za 2 minuty}

- počet slov chybně přečtených ve stejném časovém úseku.

2. Tiché čtení: text Děvečka ${ }^{5}$ text je rozdělen na 3 odstavce a je změněn princip zadávání testu. Při testování se nehodnotí počet slov přečtených za 3 minuty, ale čas potřebný k přečtení 1 . odstavce (po úpravě končící větou „Jen nám tady trochu poklidíš a zase tě pustíme“, celkem obsahuje 265 slov). Porozumění je ověřováno ihned po dočtení. Pro zhodnocení úrovně porozumění čteného textu jsou žáci nejdříve instruováni, aby co nejpřesněji a nejkonkrétněji popsali vše, co si z prríběhu pamatují. To, co v samostatném vyprávění zmíní, je v záznamovém archu hodnoceno 2 body. Ty informace, které žáci a studenti samostatně neuvedou, jsou následně ověřovány pomocí standardizovaných otázek. Pokud na otázku odpoví správně, dostanou 1 bod. Pokud si ani s pomocí otázky nevybaví odpověd', dostanou 0 bodů. Pro vyhodnocení testu nás tedy zajímá:

- počet sekund, za který žák či student přečte 1. odstavec - počet bodů získaných při ověřování porozumění

\section{Výsledky a normy:}

Níže uvádíme záznamové archy následované normami. Použité texty je nutné si opatřit z citovaných diagnostických baterií. Normy byly zpracovány do tabulek uvedených na následujících stranách -zvlášt' pro žáky 9. tříd a 1. ročníků a rozděleny podle typu školy. Nejprve vždy uvádíme tabulku pro hlasité čtení, následuje tabulka pro hodnocení počtu chyb, poté jsou uvedeny normy pro tiché čtení a porozumění. $V$ závěru je tabulka zobrazující orientační posouzení výkonů žáků $\mathrm{s}$ VPU ( $\mathrm{v}$ průběhu sběru dat však nebyli odlišováni dyslektici od žákủ a studentů

\footnotetext{
${ }^{4}$ Bednářová, J. et al. (2015). Diagnostika schopností a dovedností v oblasti čtení a psaní. PPP Brno.

${ }^{5}$ Cimlerová, P., Pokorná, D. Chalupová, E. et al. (2007). Diagnostika specifických poruch učení u adolescentů a dospělých osob. Praha: IPPP.
} 

ZŠ a 1. ročníků SŠ

s jiným typem VPU). Na základě zjištěných informací výrazně doporučujeme srovnávat výkony žáků s výkony žáků ze stejného typu školy (at' už v př́ípadě ZŠ vs. gymnázií u 9. tříd, tak také u studentů 1. ročníků SŠ vs. SOU vs. gymnázium). Je rovněž nutné vzít v úvahu místní charakter norem, vytvořených v rámci Moravskoslezského kraje. 
Hana Sokolová, Hynek Cígler: Zkoušky čtenářských dovedností: Normativní česká data pro studenty 9. tř́íd ZŠ a 1. ročníků SŠ

Jméno a př́ijmení:

Třída:

Škola:

Datum vyšetření:

Zkouška hlasitého čtení

Instrukce: Přečti nahlas tento článek, začni nadpisem a čti tak dlouho, dokud tě nezastavím. Při čtení

dávej pozor, o čem čteš, protože se tě na př́běh potom budu ptát.

\begin{tabular}{|l|c|l|c|c|c|c|c|}
\hline & 1. min. & & 2. min & & $1 .+2$. min. & Percentil & ČQ \\
\hline $\begin{array}{l}\text { Počet celkem } \\
\text { přečtených slov: }\end{array}$ & & & & -- & -- & -- \\
\hline $\begin{array}{l}\text { Počet chybně } \\
\text { přečtených slov: }\end{array}$ & & + & & $=$ & & & \\
\hline $\begin{array}{l}\text { Počet správně } \\
\text { přečtených slov }\end{array}$ & & + & & $=$ & & & \\
\hline
\end{tabular}

\section{Technika:}

Porozumění: 
Hana Sokolová, Hynek Cígler: Zkoušky čtenářských dovedností: Normativní česká data pro studenty 9. tř́íd ZŠ a 1. ročníků SS̆

Jméno a př́ijmení:

Třída:

Škola:

Datum vyšetření:

Tiché čtení s porozuměním

Instrukce: Tento text budeš číst potichu, pouze nadpis přečteš nahlas a pak budeš pokračovat pro sebe tichým čtením. Až dočteš na konec prvního odstavce (ukážeme), řekneš mi. Je důležité, abys dával/a pozor, o čem čteš, protože budu chtít, abys mi př́běh povyprávěl/a.

Čas čtení 1. odstavce (tj. 265 slov):

\begin{tabular}{|c|c|c|}
\hline Čas & Percentil & ČQ \\
\hline & & \\
\hline
\end{tabular}

\section{Ověřování porozumění:}

„Ted' mi řekni všechno, co si z prríběhu pamatuješ. Zkus mi povyprávět prečtený prríběh co nejkonkrétněji a nejpřesněji“

\begin{tabular}{|c|c|c|c|}
\hline 1 & $\begin{array}{l}\text { Ve vsi pod jakou horou se příběh } \\
\text { odehrává }\end{array}$ & pod Blaníkem & 0112 \\
\hline 2 & Kdy byl oběd? & pozdě/ji než obvykle, po poledni & $\begin{array}{lll}0 & 1 & 2\end{array}$ \\
\hline 3 & Co se ozvalo na návsi během oběda? & $\begin{array}{l}\text { trouba, } \\
\text { slouha troubil/houkal/svolával }\end{array}$ & $0 \quad 12$ \\
\hline 4 & Proč slouha troubil? & $\begin{array}{l}\text { at'vyženou ovce, protože bral ovce, } \\
\text { sháněl ovce, šel s ovcemi na pastvu }\end{array}$ & $0 \quad 12$ \\
\hline 5 & $\begin{array}{l}\text { Co zjistila děvečka, když přišla na } \\
\text { náves? }\end{array}$ & $\begin{array}{l}\text { že už je slouha pryč, že slouhu } \\
\text { nestihla, že jde pozdě/ nestihla to }\end{array}$ & $\begin{array}{lll}0 & 1 & 2\end{array}$ \\
\hline 6 & Jak to vyřešila? & $\begin{array}{l}\text { musela odvést ovce sama, šla } \\
\text { s ovcemi za ním }\end{array}$ & $\begin{array}{lll}0 & 1 & 2\end{array}$ \\
\hline 7 & Co se stalo, když hnala ovce? & $\begin{array}{l}\text { jedna se zaběhla, oddělila od stáda, } \\
\text { utekla }\end{array}$ & $0 \quad 12$ \\
\hline 8 & Kam ovečka s děvečkou vešly? & do skály, jeskyně & $0 \quad 1 \quad 2$ \\
\hline 9 & Co se stalo se skálou sotva byly uvnitř? & zarachotilo se, skála se zavřela & 0112 \\
\hline 10 & $\begin{array}{l}\text { Jak se cítila děvečka, když se skála } \\
\text { zavřela? }\end{array}$ & $\begin{array}{l}\text { byla ulekaná, vystrašená .... } \\
\text { synonyma strachu }\end{array}$ & $0 \quad 12$ \\
\hline 11 & Co viděla děvečka uvnitř skály? & spící vojsko, vojáky, armádu, rytíre & 0112 \\
\hline 12 & Co dostala děvečka za úkol? & uklidit jim & $\begin{array}{lll}0 & 1 & 2\end{array}$ \\
\hline
\end{tabular}

\section{Počet bodů v porozumění:}

\begin{tabular}{|c|c|c|}
\hline Počet bodů & Percentil & ČQ \\
\hline & & \\
\hline
\end{tabular}


Hlasité čtení - Legenda o Vlčím hradu - 9. třída, N=67

\begin{tabular}{|c|c|c|c|c|}
\hline & & \multicolumn{3}{|c|}{ Počet správně přečtených slov za 2 minuty } \\
\hline Percentil & ČQ & V̌̌ichni & Ž́ & Gymnázium \\
\hline 98. & 130 & 314 & - & - \\
\hline 95. & 125 & 303 & 287 & - \\
\hline 90. & 119 & 291 & 269 & 307 \\
\hline 85. & 116 & 282 & 256 & 306 \\
\hline 80. & 113 & 271 & 251 & 299 \\
\hline 75. & 110 & 260 & 246 & 298 \\
\hline 70. & 108 & 253 & 242 & 286 \\
\hline 65. & 106 & 246 & 240 & 285 \\
\hline 60. & 104 & 242 & 238 & 273 \\
\hline 55. & 102 & 239 & 228 & 271 \\
\hline 50. & 100 & 232 & 227 & 271 \\
\hline 45. & 98 & 227 & 224 & 266 \\
\hline 40. & 96 & 224 & 223 & 260 \\
\hline 35. & 94 & 223 & 221 & 239 \\
\hline 30. & 92 & 219 & 214 & 226 \\
\hline 25. & 90 & 214 & 208 & 223 \\
\hline 20. & 87 & 206 & 188 & 215 \\
\hline 15. & 84 & 187 & 181 & 214 \\
\hline 10. & 81 & 173 & 170 & 190 \\
\hline 5. & 75 & 165 & 161 & 164 \\
\hline 2. & 70 & 136 & 125 & - \\
\hline
\end{tabular}

Hlasité čtení - Legenda o Vlčím hradu - 9. třída, N=67

\begin{tabular}{|l|c|c|c|c|}
\hline & & \multicolumn{3}{|c|}{ Počet chybně přečtených slov za 2 minuty } \\
\hline & Percentil & Všichni & ZŠ & Gymnázium \\
\hline $\begin{array}{l}\text { Horní průměr a } \\
\text { lepší }\end{array}$ & $>=66$. & 0 & 0 & 0 \\
\hline Střední průměr & $36 .-65$. & $1-2$ & $1-2$ & 1 \\
\hline Dolní průměr & $17 .-35$. & $3-4$ & $3-4$ & $2-3$ \\
\hline Podprůměr & $3 .-16$. & $5-7$ & $5-6$ & $4-6$ \\
\hline $\begin{array}{l}\text { Výrazný } \\
\text { podprůměr }\end{array}$ & $=<2$. & 8 a více & 7 a více & 7 a více \\
\hline
\end{tabular}


Tiché čtení (Děvečka) - 9. Třída, N=67

\begin{tabular}{|c|c|c|c|c|}
\hline & & \multicolumn{3}{|c|}{ Čas (v sekundách) potřebný na přečtení 1. odstavce } \\
\hline Percentil & ČQ & Všichni & ZS & Gymnázium \\
\hline 98. & 130 & 68,34 & 68,00 & - \\
\hline 95. & 125 & 70,75 & 74,80 & - \\
\hline 90. & 119 & 76,00 & 80,80 & 69,00 \\
\hline 85. & 116 & 82,15 & 88,20 & 75,00 \\
\hline 80. & 113 & 88,00 & 89,60 & 77,00 \\
\hline 75. & 110 & 89,75 & 92,00 & 85,00 \\
\hline 70. & 108 & 93,10 & 94,00 & 87,00 \\
\hline 65. & 106 & 95,00 & 95,00 & 88,00 \\
\hline 60. & 104 & 96,00 & 98,40 & 95,00 \\
\hline 55. & 102 & 98,30 & 100,60 & 96,00 \\
\hline 50. & 100 & 100,50 & 102,00 & 96,00 \\
\hline 45. & 98 & 101,85 & 104,80 & 96,00 \\
\hline 40. & 96 & 105,00 & 108,40 & 100,00 \\
\hline 35. & 94 & 107,65 & 112,00 & 101,00 \\
\hline 30. & 92 & 111,80 & 116,20 & 105,00 \\
\hline 25. & 90 & 115,00 & 121,00 & 105,00 \\
\hline 20. & 87 & 120,60 & 124,80 & 109,00 \\
\hline 15. & 84 & 125,90 & 132,80 & 114,00 \\
\hline 10. & 81 & 135,20 & 139,80 & 115,00 \\
\hline 5. & 75 & 162,20 & 165,00 & - \\
\hline 2. & 70 & 178,86 & - & - \\
\hline
\end{tabular}

Tiché čtení (Děvečka) - 9. třída, $\mathrm{N}=67$

\begin{tabular}{|c|c|c|c|c|}
\hline & & \multicolumn{3}{|c|}{ Porozuméní (počet bodů za 1. odstavec) } \\
\hline Percentil & $\check{\mathbf{C}} \mathbf{\text { Všichni }}$ & $\mathbf{Z}$ S & Gymnázium \\
\hline 98. & 130 & - & - & - \\
\hline 95. & 125 & 22 & 21 & - \\
\hline 90. & 119 & 21 & 20 & 22 \\
\hline 85. & 116 & 20 & 19 & 21 \\
\hline 80. & 113 & 19 & 19 & 21 \\
\hline 75. & 110 & 19 & 18 & 20 \\
\hline 70. & 108 & 18 & 17 & 19 \\
\hline 65. & 106 & 18 & 16 & 19 \\
\hline 60. & 104 & 17 & 15 & 18 \\
\hline 55. & 102 & 15 & 14 & 18 \\
\hline 50. & 100 & 15 & 14 & 17 \\
\hline 45. & 98 & 14 & 13 & 15 \\
\hline 40. & 96 & 14 & 11 & 15 \\
\hline 35. & 94 & 12 & 11 & 14 \\
\hline 30. & 92 & 11 & 10 & 14 \\
\hline 25. & 90 & 10 & 10 & 12 \\
\hline 20. & 87 & 9 & 9 & 9 \\
\hline 15. & 84 & 9 & 8 & 7 \\
\hline 10. & 81 & 8 & 4 & - \\
\hline 5. & 75 & 7 & 5 & 3 \\
\hline 2. & 70 & 3 & & \\
\hline
\end{tabular}


Hlasité čtení - Legenda o Vlčím hradu - 1. ročník, N=137

\begin{tabular}{|c|c|c|c|c|c|}
\hline & & \multicolumn{4}{|c|}{ Počet správně přečtených slov za 2 minuty } \\
\hline Percentil & ČQ & V̌̌ichni & SOU & Š & Gymnázium \\
\hline 98. & 130 & 308 & - & 300 & - \\
\hline 95. & 125 & 298 & 279 & 292 & 315 \\
\hline 90. & 119 & 280 & 245 & 277 & 304 \\
\hline 85. & 116 & 276 & 234 & 274 & 297 \\
\hline 80. & 113 & 270 & 228 & 269 & 288 \\
\hline 75. & 110 & 262 & 226 & 259 & 278 \\
\hline 70. & 108 & 259 & 224 & 251 & 271 \\
\hline 65. & 106 & 250 & 223 & 245 & 269 \\
\hline 60. & 104 & 245 & 222 & 244 & 266 \\
\hline 55. & 102 & 239 & 203 & 239 & 261 \\
\hline 50. & 100 & 232 & 187 & 232 & 260 \\
\hline 45. & 98 & 230 & 175 & 230 & 258 \\
\hline 40. & 96 & 225 & 163 & 228 & 250 \\
\hline 35. & 94 & 221 & 154 & 221 & 246 \\
\hline 30. & 92 & 213 & 143 & 213 & 239 \\
\hline 25. & 90 & 189 & 136 & 208 & 233 \\
\hline 20. & 87 & 180 & 128 & 187 & 225 \\
\hline 15. & 84 & 159 & 119 & 177 & 215 \\
\hline 10. & 81 & 136 & 107 & 158 & 189 \\
\hline 5. & 75 & 120 & 103 & 124 & 131 \\
\hline 2. & 70 & 100 & 100 & 96 & 124 \\
\hline
\end{tabular}

Hlasité čtení - Legenda o Vlčím hradu - 1. ročník, N=137

\begin{tabular}{|l|c|c|c|c|c|}
\hline & & \multicolumn{4}{|c|}{ Počet chybně přečtených slov za 2 minuty } \\
\hline & Percentil & Všichni & SOU & SŠ & Gymnázium \\
\hline Výr. nadprůměr & $>=98$. & 0 & 0 & 0 & 0 \\
\hline Nadprůměr & $86 .-97$. & 0 & 1 & 0 & 0 \\
\hline Horní průměr & $66 .-85$. & 0 & 2 & 0 & 0 \\
\hline Střední průměr & $36 .-65$. & $1-2$ & $3-4$ & $1-2$ & 1 \\
\hline Dolní průměr & $17 .-35$. & $3-4$ & $5-6$ & $3-4$ & 2 \\
\hline Podprůměr & $3 .-16$. & $5-10$ & $7-10$ & $5-12$ & $3-4$ \\
\hline Výr. podprůměr & $=<2$. & 11 a více & 11 a více & 13 a více & 5 a více \\
\hline
\end{tabular}


Tiché čtení (Děvečka) - 1. ročník, N=137

\begin{tabular}{|c|c|c|c|c|c|}
\hline & & \multicolumn{4}{|c|}{ Čas (v sekundách) potřebný na přečtení 1. Odstavce } \\
\hline Percentil & ČQ & Všichni & SOU & Š̌ & Gymnázium \\
\hline 98. & 130 & 67,88 & 81,00 & 73,76 & 47,00 \\
\hline 95. & 125 & 77,00 & 87,50 & 77,45 & 58,65 \\
\hline 90. & 119 & 82,80 & 97,00 & 81,90 & 77,20 \\
\hline 85. & 116 & 87,70 & 103,00 & 89,35 & 83,00 \\
\hline 80. & 113 & 92,60 & 107,00 & 93,00 & 84,40 \\
\hline 75. & 110 & 95,00 & 114,00 & 97,25 & 87,25 \\
\hline 70. & 108 & 98,40 & 119,00 & 102,00 & 88,60 \\
\hline 65. & 106 & 102,00 & 122,50 & 103,30 & 92,35 \\
\hline 60. & 104 & 103,40 & 124,00 & 108,60 & 94,40 \\
\hline 55. & 102 & 109,00 & 127,50 & 110,00 & 96,35 \\
\hline 50. & 100 & 111,00 & 133,00 & 113,50 & 98,00 \\
\hline 45. & 98 & 113,90 & 135,50 & 118,95 & 99,00 \\
\hline 40. & 96 & 119,00 & 154,00 & 120,00 & 101,20 \\
\hline 35. & 94 & 122,00 & 159,50 & 122,85 & 103,00 \\
\hline 30. & 92 & 125,00 & 165,00 & 125,00 & 107,80 \\
\hline 25. & 90 & 129,50 & 169,50 & 129,00 & 111,00 \\
\hline 20. & 87 & 134,40 & 183,00 & 132,00 & 111,80 \\
\hline 15. & 84 & 149,90 & 187,50 & 143,30 & 113,85 \\
\hline 10. & 81 & 168,20 & 207,00 & 153,50 & 128,30 \\
\hline 5. & 75 & 208,10 & 219,50 & 230,00 & 144,30 \\
\hline 2. & 70 & 236,48 & - & 260,72 & - \\
\hline
\end{tabular}

Tiché čtení (Děvečka) - 1. ročník, N=137

\begin{tabular}{|c|c|c|c|c|c|}
\hline & & \multicolumn{4}{|c|}{ Porozumění (počet bodů za 1. odstavec) } \\
\hline Percentil & ČQ & V̌̌ichni & SOU & Sธ̌ & Gymnázium \\
\hline 98. & 130 & - & 22 & 23 & - \\
\hline 95. & 125 & 22 & 19 & 22 & 22 \\
\hline 90. & 119 & 21 & 18 & 21 & 21 \\
\hline 85. & 116 & 19 & 17 & 19 & 21 \\
\hline 80. & 113 & 19 & 16 & 18 & 20 \\
\hline 75. & 110 & 18 & 15 & 18 & 19 \\
\hline 70. & 108 & 18 & 15 & 17 & 19 \\
\hline 65. & 106 & 17 & 15 & 16 & 18 \\
\hline 60. & 104 & 16 & 14 & 16 & 18 \\
\hline 55. & 102 & 16 & 14 & 15 & 18 \\
\hline 50. & 100 & 15 & 13 & 14 & 17 \\
\hline 45. & 98 & 14 & 12 & 13 & 16 \\
\hline 40. & 96 & 14 & 11 & 13 & 16 \\
\hline 35. & 94 & 13 & 11 & 12 & 15 \\
\hline 30. & 92 & 12 & 10 & 11 & 15 \\
\hline 25. & 90 & 12 & 8 & 10 & 14 \\
\hline 20. & 87 & 11 & 5 & 9 & 14 \\
\hline 15. & 84 & 10 & 3 & 9 & 13 \\
\hline 10. & 81 & 8 & 1 & 8 & 13 \\
\hline 5. & 75 & 5 & 0 & 6 & 12 \\
\hline 2. & 70 & 2 & & 2 & 11 \\
\hline
\end{tabular}




\section{Žáci s VPU (N=18)}

\begin{tabular}{|l|c|c|c|c|c|c|}
\hline & & & \multicolumn{2}{|c|}{ Hlasité čtení (2 min) } & \multicolumn{2}{c|}{ Tiché čtení (1. část) } \\
\hline & VS & Percentil & Počet slov & Chyby & $\begin{array}{c}\text { Rychlost } \\
\text { (s) }\end{array}$ & Porozumění \\
\hline Nadprůměr & $>=116$ & $>=85$. & 221 a více & 2 a méně & $\begin{array}{c}108 \text { a } \\
\text { méně }\end{array}$ & 22 a více \\
\hline Horní průměr & $\begin{array}{c}105- \\
115\end{array}$ & $61 .-84$. & $177-220$ & $3-4$ & $121-109$ & $19-21$ \\
\hline $\begin{array}{l}\text { Střední } \\
\text { průměr }\end{array}$ & $96-104$ & $40 .-60$. & $153-176$ & $5-6$ & $153-122$ & $16-18$ \\
\hline Dolní průměr & $85-95$ & $16 .-39$. & $118-152$ & $7-11$ & $201-154$ & $13-15$ \\
\hline Podprůměr & $<=84$ & $<=15$. & $\begin{array}{c}117 \text { a } \\
\text { méně }\end{array}$ & 12 a více & 202 a více & 12 a méně \\
\hline
\end{tabular}

